\title{
Essential Oil Content and Composition of Almescla Resin (Protium spruceanum (Benth.) Engl., Burseraceae
}

\author{
Maria Carolina Oliva Brasil ${ }^{1}$, Guilherme Araújo Lacerda ${ }^{1,2}$, Sonia Ribeiro Arrudas ${ }^{2}$ \\ \& Maria das Dores Magalhães Veloso ${ }^{2}$ \\ ${ }^{1}$ Nucleus of Studies in Medicinal Plants, Health College Ibituruna, Montes Claros, Minas Gerais, Brazil \\ ${ }^{2}$ Department of General Biology, Center for Biological and Health Sciences, State University of Montes Claros, \\ Darcy Ribeiro University Campus, Montes Claros, Minas Gerais, Brazil \\ Correspondence: Sonia Ribeiro Arrudas, State University of Montes Claros, Darcy Ribeiro University Campus, \\ Montes Claros, Minas Gerais, Brazil. Tel: 55-038-999-913-595. E-mail: sonia.arrudas@unimontes.br
}

Received: July 22, $2018 \quad$ Accepted: August 31, $2018 \quad$ Online Published: October 15, 2018

doi:10.5539/jas.v10n11p442 URL: https://doi.org/10.5539/jas.v10n11p442

\begin{abstract}
In recent decades, there has been a significant increase in interest in natural therapies. In this way, plants with therapeutic properties constitute an important source of biologically active compounds. The species Protium spruceanum (Benth.) Engl., popularly known as Almescla is widely used in folk medicine, with a wide geographical distribution, often found in gallery forests and palm swamps (veredas), thus easily accessible. The objective of this work was to evaluate the oil yield of the leaves and stem, as well as the chemical composition of Almescla resin collected in a palm swamp in the north-central region of Minas Gerais. After drying, the botanical samples were triturated until a fine powder was obtained and the particle size of the leaf sample standardized through sieves. The test was carried out in triplicate, the oil being obtained from the hot extraction method in Soxhlet with solvent Hexane P.A. The resin was subjected to chromatographic analysis and infrared spectroscopy, by the preparation of $\mathrm{KBr}$ pellets $(1 \% \mathrm{~m} / \mathrm{m})$. For the leaf sample, an average yield of $3.33 \%$ was obtained and for the stem, an average yield of $1.40 \%$. The resin had the major chemical compound $\alpha$-phellandrene (58.18-71.25\%). It is concluded that, Almescla has a great oil yield, and the chemical analysis showed that the species has a great medicinal potential to be exploited.
\end{abstract}

Keywords: alpha-phellandrene, medicinal plant, plant extract, volatile oil

\section{Introduction}

Natural products derived from plants have been an alternative source of drugs (Tulp \& Bohlin, 2004). These products have great structural and chemical diversity that can be used as prototype or model for more specific and efficient drug synthesis (Lang et al., 2008). Edris (2007) describes plant essential oils as compounds with great therapeutic and pharmacological potential.

Essential oils, products of secondary metabolism, are natural, volatile and complex (Machado \& Fernandes Junior, 2011). These compounds are formed by various constituents such as terpene hydrocarbons, alkaloids, aldehydes, ketones, phenols, esters, oxides, peroxides, furans, organic acids, lactones, coumarins and even sulfur compounds (Silveira, Busato, Costa, \& Costa Junior, 2012). According to Martins (2012), they are characterized by strong odor and often exert a function of attracting insect pollinators and protection against herbivores. Known by the bactericidal, fungicidal action and medicinal properties, in folk medicine are used as antimicrobial, anti-inflammatory and food preservation, among other actions (Bakkali, Averbeck, Averbeck, \& Idaomar, 2008).

The Burseraceae family, found in tropical and subtropical regions, is composed of 16 genera, with seven genera in Brazil, Bursera, Commiphora, Crepidospermum, Dacryodes, Protium, Tetragastris and Trattinnickia. Protium is the most representative, with 68 species described (Flora do Brasil, 2018a). Several genera of this family are producers of an oily sap, rich in essential oil and triterpenes, widely used in folk medicine (Bandeira, Pessoa, Trevisan, \& Lemos, 2002).

The species Protium spruceanum (Benth.) Engl., popularly known as Almescla, Almecegueira or Breu, is a resinous and aromatic plant with a wide geographical distribution in Brazil (Flora do Brasil, 2018b). Present in the Amazon, Cerrado and Atlantic Forest domains, it is a medium-sized tree that reaches from 8 to $14 \mathrm{~m}$ in 
height, has a dense rounded crown, straight and cylindrical trunk, with rough and thin bark, 25 to $40 \mathrm{~cm}$ in diameter. The leaves are compound, pinnate, alternate, with common axis (petiole + rachis) of $10-20 \mathrm{~cm}$ in length. The leaflets are subcoriaceous in number from 3 to 5 , slightly discolored, glabrous on the upper face and pubescent on the ribs on the underside, $5-10 \mathrm{~cm}$ long, $3-4 \mathrm{~cm}$ wide, the main vein prominent in both faces, with thin trichomes ranging from dense to sparse on the underside and venation of brochidodromous (Lima et al., 2014; Loureiro, Silva, \& Alencar, 1979). It also has inflorescences in axillary ramose panicles of $2-3 \mathrm{~cm}$ in length. Its fruits are ellipsoid, substipitate, slightly oblique, with a slightly curved top, rounded base and often persistent stigma, dehiscent, usually open in 2-3 reddish valves, internally reddish and reticulated, the exocarp being sub woody, smooth, glossy, glabrous, when immature is yellow and when ripe red. The mesocarp is relatively thin, fleshy and reddish; the white and spongy aryloid completely enveloping the pyrenean (Melo, Macedo, \& Daly, 2007). The species blooms during the months from September to November and bear fruits from January (Loureiro et al., 1979). The resin of the species has a pleasant aroma, when exuded from the stem it is colorless and after drying it becomes whitish (Lima et al., 2014).

Due to its pleasant aroma, the Almescla resin (Protium spp.) has been widely used in aromatherapy, being widely used in popular medicine, as an analgesic, healing and expectorant (Machado, Zoghbi, \& Andrade, 2003). Rodrigues et al. (2013), carried out a study with crude ethanolic extract of leaves of P. spruceanum, submitted to the liquid partition, obtaining the hexane fraction and methanolic fraction, where promising results of the anti-inflammatory activity were observed for the crude ethanolic extract and its fractions, which were attributed to the mixture of $\alpha$ - and $\beta$-amyrins. When evaluating the analgesic activity, the same authors suggest that the hexane fraction has relevant central and peripheral antinociceptive activity, which can be attributed to the mixture of $\alpha$ - and $\beta$-amyrins. Gobbo-Neto and Lopes (2007) state that exploring plant resources may lead to the identification of important secondary metabolites that can serve as drugs or guide to the development of new therapeutic substances.

In this perspective, the objective of this work was to evaluate the yield of the essential oil of the leaves and stem, as well as the chemical composition of the resin of Almescla (Protium spruceanum (Benth.) Engl., Burseraceae), native of the central north region of Minas Gerais, Brazil.

\section{Method}

\subsection{Collection of the Botanical Sample}

Leaves, stems of the terminal branches and Almescla resin were collected in September 2016, in a palm swamp located in the municipality of Buenópolis, north-central region of Minas Gerais, Brazil. According to the Köppen-Geiger classification, the climate of the region is Aw, a tropical climate with a dry winter season, with an annual average temperature of $22.5^{\circ} \mathrm{C}$ and average annual rainfall of $1170 \mathrm{~mm}$. An exsicata of the species is incorporated to the Montes Claros Herbarium collection, Minas Gerais-MCMG (State University of Montes Claros) under historic preservation number of 5219.

\subsection{Granulometry}

The leaf and stem samples were dried in the shade at room temperature until reaching constant weight, and then crushed in a $600 \mathrm{~W}$ blender to obtain a fine powder. The granulometry of the leaf powder was standardized by means of sieves (ABNT 20, opening at $0.85 \mathrm{~mm}$ Tyler 20 and ABNT 40, opening at $0.42 \mathrm{~mm}$ Tyler 35) for extraction of the oil (Brandão, 2007).

\subsection{Extraction of Essential Oil}

The assay was performed in triplicate, where empty cellulose cartridges were identified and weighed, using an analytical balance with an accuracy of $0.1 \mathrm{mg}$ and its mass was recorded (Mcv). Subsequently, $5 \mathrm{~g}$ of each sample, previously dried and crushed, were weighed into the tared cellulose cartridge, the mass of the sample was recorded (Mae). The cartridge containing the sample was placed inside the Soxhlet extractor model TE- 188 . In the flat bottom flask of $250 \mathrm{~mL}$, female grinding joint $\mathrm{J} 24 / 40$, it was added $150 \mathrm{~mL}$ of Hexane P.A., and the extraction set was then set up (heating plate with temperature control, flat bottom flask, Soxhlet $350 \mathrm{~mm}$ extractor JM 24/40 and JF 55/50 and Allihn type condenser (ball), $386 \mathrm{~mm}$ male grinding joint J 55/50). After assembly, water was charged to flow through the condenser, heated to the boiling point of the solvent (approximately $70^{\circ} \mathrm{C}$ ), reflux controlling at about 12-14 cycles per hour. Hexane P.A. was used following the methodology adapted from Pinho et al. (2009).

The extraction was maintained for 6 hours (Adapted from IAL, 1985; Moretto \& Fett, 1998). The cartridges were dried at room temperature after 7 days when they were weighed and the mass of the dried sample cartridge checked after extraction (Mcpe). The obtained crude oil was stored in amber glass vials identified and 
incorporated into the extract collection center of the Nucleus of Studies in Medicinal Plants (Núcleo de Estudos em Plantas Medicinais-NEPM), Health college Ibituruna (Faculdade de Saúde Ibituruna-FASI).

\subsection{Obtaining Essential Oil Yield}

$$
\text { Oil content }(\%)=\frac{\text { Mae }- \text { Mpe }}{\text { Mae }} \times 100
$$

Where,

Mae $=$ Dry sample mass before solvent extraction $(\mathrm{g})$; Mpe $=$ Dry sample mass after solvent extraction $(\mathrm{g})$. (Santos, Arruda, Brasil, \& Lacerda, 2017).

$$
\text { Mpe }=\text { Mcpe }- \text { Mcv }
$$

Mcpe $=$ Cartridge mass with dry sample after extraction $(\mathrm{g}) ; \mathrm{Mcv}=$ Empty cartridge mass $(\mathrm{g})$.

\subsection{Resin Analysis by Infrared Spectroscopy (IR)}

All resin samples were subjected to infrared spectroscopy analysis by the preparation of $\mathrm{KBr}$ pellets $(1 \% \mathrm{~m} / \mathrm{m})$. In all cases, eight scans were performed, with a resolution of $2 \mathrm{~cm}^{-1}$.

\subsection{Chromatographic Conditions Employed}

Chromatographic analyzes were performed on Agilent Technologies (GC 7890A) gas chromatograph equipped with mass detector (CG-MS) and DB-5MS capillary column (Agilent Technologies, $30 \mathrm{~m}$ long $\times 0.25 \mathrm{~mm}$ internal diameter $\times 0.25 \mu \mathrm{m}$ film thickness). Helium (99.9999\% purity) was used as the entrainment gas at a rate of $1 \mathrm{~mL} \mathrm{~min}{ }^{-1}$. Using a self-injector (CTC combiPaL), $1 \mu \mathrm{L}$ of the sample was injected into the chromatograph at a 1:10 split ratio. The split/splitless injector was maintained at $220^{\circ} \mathrm{C}$. The chromatographic column initially at $160{ }^{\circ} \mathrm{C}$, isotherm for $2 \mathrm{~min}$, was heated at a rate of $2{ }^{\circ} \mathrm{C} \mathrm{min}-1$ to $200{ }^{\circ} \mathrm{C}$ and then up to $240{ }^{\circ} \mathrm{C}$ at a rate of $10^{\circ} \mathrm{C}$ $\mathrm{min}^{-1}$. After separation of the compounds the temperature was raised to $300^{\circ} \mathrm{C}$ and kept for 3 minutes (post run). The interface temperature was maintained at $240{ }^{\circ} \mathrm{C}$ and the ionization was performed with $70 \mathrm{eV}$ impact. The scanning range of $\mathrm{m} / \mathrm{z}$ was from 30 to $600 \mathrm{Da}$. The analyzes were carried out in the Laboratory of Instrumental Chemistry of the Institute of Agrarian Sciences, Federal University of Minas Gerais, Brazil.

\subsection{Data Analysis}

The mean, standard deviation and coefficient of variation of the oil contents of each sample were calculated. Data analysis was performed using Excel 2013 software.

\section{Results and Discussion}

Through the analysis of the obtained results, it was possible to verify the yield of the extraction of the essential oil, obtained from five grams of dry leaf and stem sample. For the leaf sample, mean yield was 3.33\% (Table 1) and for the stem of $1.40 \%$ (Table 2). Both the yield found for the leaves and that found for the stem of the terminal branches were higher than those of other studies with this same species (Table 3 ).

Table 1. Average values of the oil content of the Almescla leaf (Protium spruceanum) extracted (\% on dry basis), standard deviation obtained and coefficient of variation

\begin{tabular}{llllll}
\hline Identification & Mcv & Mae & Mcpe & Mpe & Oil content (\%) \\
\hline Extraction 1 & 2.96 & 5.00 & 7.80 & 4.84 & 3.20 \\
Extraction 2 & 3.17 & 5.00 & 8.00 & 4.83 & 3.40 \\
Extraction 3 & 2.96 & 5.00 & 7.80 & 4.83 & 3.40 \\
\hline Average & 3.03 & 5.00 & 7.87 & 4.83 & 3.33 \\
Standard deviation & 0.10 & 0.00 & 0.09 & 0.00 & 0.09 \\
Coefficient of variation & 1.53 & 5.00 & 12.09 & 4.66 & 2.10 \\
\hline
\end{tabular}

Note. Mae = Dry sample mass before solvent extraction $(\mathrm{g}) ;$ Mpe $=$ Dry sample mass after solvent extraction $(\mathrm{g})$; Mcpe $=$ Cartridge mass with dry sample after extraction $(\mathrm{g}) ; \mathrm{Mcv}=$ Empty cartridge mass $(\mathrm{g})$; Mpe = Mcpe Mcv.

Comparing the study sample with those used by Zoghbi et al. (2002) and by Machado et al. (2003), it is possible to observe significant differences regarding locality, climate and oil extraction procedure (Table 3), possible explanation for the different oil contents found. The content and composition of essential oils may vary according to botanical origin, geographical parameters and soil type, vegetative cycle, climatic factors and the 
obtaining procedure (Hussain \& Anwar, 2008; Machado et al., 2003; Probst, 2012). Several studies also take into account the period of plant material collection, drying conditions and extraction time of the essential oil to obtain higher oil yields (Agostini et al., 2005; Corrêa, Bertolucci, Pinto, Reis, \& Alves, 2004; Marco, Innecco, Mattos, Borges, \& Medeiros Filho, 2006).

Table 2. Average values of the oil content of the Almescla stem of terminal branches (Protium spruceanum) extracted (\% on dry basis), standard deviation obtained and coefficient of variation

\begin{tabular}{llllll}
\hline Identification & Mcv & Mae & Mcpe & Mpe & Oil content (\%) \\
\hline Extraction 1 & 4.66 & 5.00 & 9.69 & 4.97 & 0.60 \\
Extraction 2 & 3.31 & 5.00 & 8.24 & 4.92 & 1.60 \\
Extraction 3 & 3.16 & 5.00 & 8.07 & 4.90 & 2.00 \\
\hline Average & 3.71 & 5.00 & 8.67 & 4.93 & 1.40 \\
Standard deviation & 0.67 & 0.00 & 0.73 & 0.03 & 0.36 \\
Coefficient of variation & 2.18 & 5.00 & 13.00 & 4.80 & 6.25 \\
\hline
\end{tabular}

Note. Mae = Dry sample mass before solvent extraction $(\mathrm{g}) ; \mathrm{Mpe}=$ Dry sample mass after solvent extraction $(\mathrm{g})$; Mcpe $=$ Cartridge mass with dry sample after extraction $(\mathrm{g}) ; \mathrm{Mcv}=$ Empty cartridge mass $(\mathrm{g})$; Mpe = Mcpe Mcv.

Table 3. Values found of essential oil yield in other studies with the same species and species of the same genus

\begin{tabular}{|c|c|c|c|c|c|}
\hline References & Species & $\begin{array}{l}\text { Location of } \\
\text { collection (State) }^{a}\end{array}$ & Botanical part & Time (hours) & Oil content $(\%)$ \\
\hline Present study & P. spruceanum & MG & Leaves & 6 & 3.33 \\
\hline Zoghbi et al., 2002 & P. spruceanum & $\mathrm{PA}$ & Leaves & 4 & 0.3 \\
\hline Machado et al., 2003 & P. spruceanum & $\mathrm{PA}$ & Leaves & 4 & $0.2-0.4$ \\
\hline Pontes et al., 2007a & P. heptaphyllum & $\mathrm{PE}$ & Leaves & 2 & 0.7 \\
\hline Citó et al., 2006 & P. heptaphyllum & MA & Leaves & 2.5 & 0.015 \\
\hline Pontes et al., 2010 & P. bahianum & PE & Leaves & 2 & 0.08 \\
\hline \multirow[t]{2}{*}{ Moraes et al., 2009} & P. giganteum & $\mathrm{PE}$ & Leaves & 2 & 0.05 \\
\hline & P. aracouchini & & & 2 & 0.04 \\
\hline Present study & P. spruceanum & MG & $\begin{array}{l}\text { Stem of terminal } \\
\text { branches }\end{array}$ & 6 & 1.40 \\
\hline Machado et al., 2003 & P. spruceanum & PA & Thin branches & 4 & $0.1-0.2$ \\
\hline Zoghbi et al., 2002 & P. spruceanum & PA & Bark & 4 & 1.7 \\
\hline Ramos et al., 2000 & P. spruceanum & $\mathrm{AM}$ & Resin & 4 & $0.10-2.23$ \\
\hline Zoghbi et al., 2002 & P. spruceanum & PA & Resin & 4 & 3 \\
\hline Machado et al., 2003 & P. spruceanum & PA & Fresh resin & 4 & $0.1-4.0$ \\
\hline Lima et al., 2014 & P. spruceanum & $\mathrm{AM}$ & Fresh resin & 4 & 10.12 \\
\hline \multirow[t]{2}{*}{ Pontes et al., 2007b } & P. bahianum & $\mathrm{PE}$ & Fresh resin & 2 & 4.6 \\
\hline & & & Aged resin & & 3.2 \\
\hline \multirow[t]{2}{*}{ Marques et al., 2010} & P. heptaphyllum ulei & $\mathrm{AC}$ & Resin & 8 & 8.6 \\
\hline & P.heptaphyllum heptaphyllum & & & & 11.3 \\
\hline \multirow[t]{4}{*}{ Silva, 2006} & P. hebetatum & $\mathrm{AM}$ & Resin & 3 & 3.1 \\
\hline & P. nitidifolium & & & & 3.33 \\
\hline & P. divarictium & & & & 2.6 \\
\hline & P. amazonicum & & & & 2.77 \\
\hline Bandeira et al., 2002 & P. heptaphyllum & $\mathrm{CE}$ & Resin & - & 11 \\
\hline Zoghbi et al., 2002 & P. spruceanum & PA & Fruit & 4 & 10.3 \\
\hline Pontes et al., 2010 & P. bahianum & $\mathrm{PE}$ & Unripe fruit & 2 & 10.5 \\
\hline Citó et al., 2006 & P. heptaphyllum & MA & Fruit & 2.5 & 0.5 \\
\hline Pontes et al., 2007a & P. heptaphyllum & PE & Fruit & 2 & 1.3 \\
\hline \multirow[t]{2}{*}{ Bandeira et al., 2002} & P. heptaphyllum & $\mathrm{CE}$ & Unripe fruit & - & 3 \\
\hline & & & Ripe fruit & - & 1.5 \\
\hline
\end{tabular}

Note. ${ }^{\text {a }}$ AC-Acre; AM-Amazonas; CE-Ceará; MA-Maranhão; MG-Minas Gerais; PA-Pará; PE-Pernambuco. * The studies used the hydrodistillation process for oil extraction, differing from the present work. 
The sample of the present study was collected in September, during the winter, during a period of no rainfall. Figueiredo et al. (2006) state that during the winter and lack of rainfall the plants are under stress, favoring higher oil contents, since, under these conditions, it is characteristic in these organisms the increase of secondary metabolites. Oliveira (2014) in his work took into account the period (dry or rainy) that the botanical material was collected, obtaining different yields of essential oil extracted from the bark of the stem of Trattinnickia burserifolia (Burseraceae) collected in the state of Roraima (Brazil), in the dry season, the collection made in March had a higher yield percentage (0.12\%) and in the rainy season, the month of August $(0.13 \%)$.

The Almescla resin presented as the major chemical compound the monoterpene hydrocarbon $\alpha$-phellandrene (64.71\%) (Table 4), followed by methyl (E)-octadec-9-enoate (18.77\%), methyl hexadecanoate (14.28\%), methyl (9Z, 12Z)-octadeca-9,12-dienoate (2.23\%) (Figure 1). Previous work done by other authors with the resin of P. spruceanum differ from these results in relation to the number, composition and predominance of the chemical constituents, such as Ramos et al. (2000), which analyzed the resin of $P$. spruceanum, collected for 3 successive years, obtained $0.10-2.23 \%$ of essential oil content, with predominance of $\beta$-phellandrene $(24.3-41.6 \%)$ and $\rho$-cymene (17.1-31.5\%), yet significant amounts of $\alpha$-phellandrene $(6.1 \%-18.4 \%)$ were also found in all samples. Machado et al. (2003) verified the seasonal variation in the composition of essential oils of leaves, thin branches and fresh resin of P. spruceanum, it was found as predominant compound in all samples and in all months the sabinene (16.2 -79.8\%), eight chemical constituents were identified in the resin, with sabinene $(61.3 \%)$ and cis-sabinene hydrate $(56.1 \%$ ) being the most prominents. Zoghbi et al. (2002), when analyzing the resin of this species, obtained $3.0 \%$ of essential oil yield, being identified 22 chemical constituents, with predominance of epi- $\alpha$-cadinol (20.4\%), and camphor (14.5\%). Yet, Lima et al. (2014), when analyzing the fresh resin of the species, obtained yield of $10.12 \%$ of essential oil and identified that all the constituents were monoterpenes with predominance of limonene $(90.93 \%)$.

Table 4. Chemical composition of Almescla resin (Protium spruceanum)

\begin{tabular}{lllllllll}
\hline Peak & $\mathbf{R t}^{\mathbf{a}}$ & Compounds & Area & Area (\%) & Area & Area (\%) & Mean & SD \\
\hline 1 & 11.942 & $\alpha$-Phellandrene & 11412183 & 58.18 & 14690981 & 71.25 & 64.71 & 6.53 \\
2 & 14.693 & methyl hexadecanoate & 3195382 & 16.29 & 2530042 & 12.27 & 14.28 & 2.01 \\
3 & 18.435 & methyl (9Z,12Z)-octadeca-9,12-dienoato & 447961 & 2.28 & 450337 & 2.18 & 2.23 & 0.05 \\
4 & 18.596 & methyl (E)-octadec-9-enoato & 4559944 & 23.25 & 2948744 & 14.30 & 18.77 & 4.47 \\
\hline
\end{tabular}

Note. ${ }^{a}$ Rt: Retention time (min.).

$\alpha$-Phellandrene (5-isopropyl-2-methyl-1,3-cyclohexadiene) is a cyclic monoterpene, found in essential oils of various plants, often used in fragrances due to its pleasant aroma. According to Lima et al. (2011), this compound has antinociceptive activity, which is corroborated by Siqueira et al. (2016) by suggesting that this substance plays an important role as an anti-inflammatory agent by modulating neutrophil migration and stabilizing mast cells. Results obtained by Hsieh et al. (2015), suggest that $\alpha$-phellandrene can induce autophagy of human liver tumor cells. Lin et al. (2016) found that this same compound induced apoptosis in leukemia in vitro cells WEHI-3 of mice and, Zhangh et al. (2017) report that $\alpha$-phellandrene may be a biological fungicide for the control of Penicillium cyclopium in post-harvest tomato fruits by significantly inhibiting the growth of mycelia and undoing cell membrane integrity. 


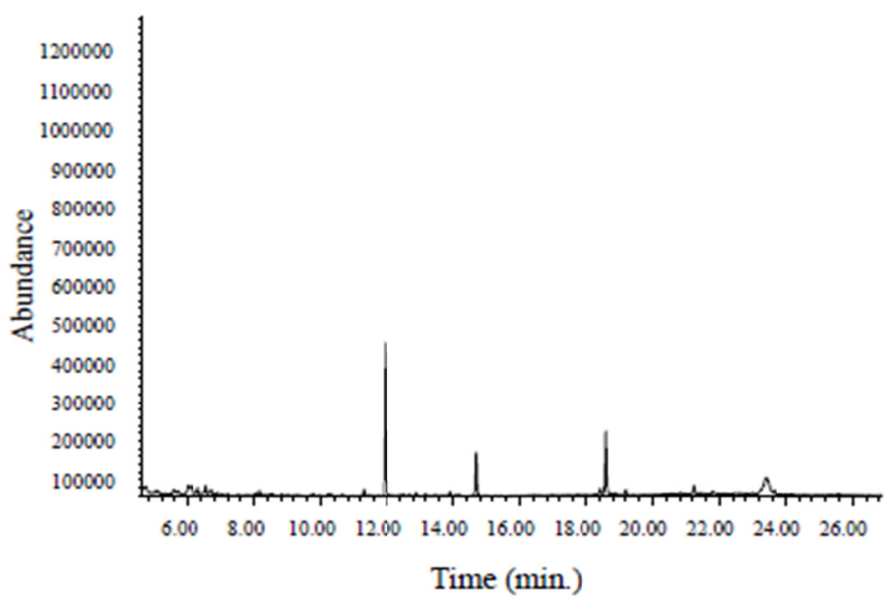

Figure 1. Chromatogram of the Almescla resin (Protium spruceanum - Burseraceae) collected in the central-north region of Minas Gerais, Brazil

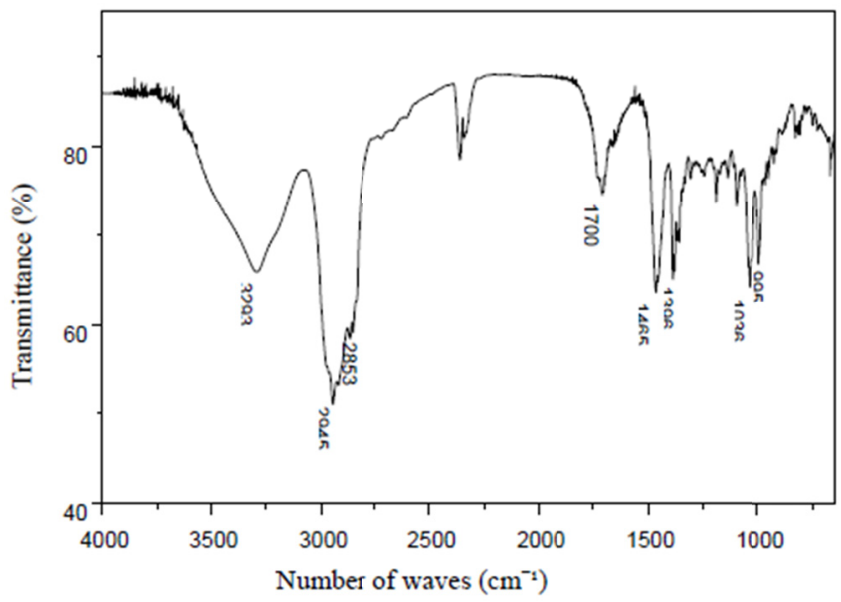

Figure 2. Analysis of $P$. spruceanum resin by infrared spectroscopy using $\mathrm{KBr}$ pellets

The infrared spectrum of the resin is shown in Figure 2, where the bands observed around 2920 and $2850 \mathrm{~cm}^{-1}$ can be attributed to stretches of sp3 carbon $\mathrm{CHs}$ present in common $\mathrm{CH}, \mathrm{CH} 2$ and $\mathrm{CH} 3$ groups in aliphatic compounds as fatty esters and fatty acids. The absorption band around $1700 \mathrm{~cm}^{-1}$ represents the $\mathrm{C}=\mathrm{O}$ stretch of the carbonyl, common in fatty acids. The absorption around $1465 \mathrm{~cm}^{-1}$ corresponds to the angular deformation band in the plane, symmetrical (CH2) and asymmetric (CH3); yet, the band around $1396 \mathrm{~cm}^{-1}$ is attributed to the angular deformation in the plane, symmetrical (CH3). The bands around 1237, 1160, $1090 \mathrm{~cm}^{-1}$ are attributed to the C-O stretch of ester (Silverstein, Webster, \& Kiemle, 2007). It is worth mentioning that the presence of the $\mathrm{O}-\mathrm{H}$ stretching wide band (bell curve), between 3400 and $2500 \mathrm{~cm}^{-1}$ indicates the presence of free fatty acids or hydroxyl-containing compounds, such as alcohols. Thus, explaining, the fact that the infrared spectrum of the resin sample showed signs of fatty acids and hydroxyl compounds.

\section{Conclusion}

By analyzing the data it is concluded that the species Protium spruceanum (Almescla) has a higher yield of essential oil of its leaves, when compared to other studies with the same species or within the same genus. The results of the chemical analysis of the resin differ from other studies regarding the number, composition and predominance of the chemical constituents, showing that the species under study has great medicinal potential to be explored, which is why we recommend further research on the species.

\section{Acknowledgments}

To the Laboratory of Plant Ecology (LEVE)-StateUniversity of Montes Claros, to the Nucleus of Studies in Medicinal Plants (NEPM) and to the Laboratory of Instrumental Chemistry-ICA/UFMG for the support. We thank 
FAPEMIG for the (BIPDT: APQ-00227-16; PPM: APQ-00623-16 and PPP: APQ-00468-15) scholarship and the CNPq for the support in the CNPq/PELD (APQ-00468-15) project to the lastauthor.

\section{References}

Agostini, F., Santos, A. C. A., Rossato, M., Pansera, M. R., Zattera, F., Wasum, R., \& Serafini, L. A. (2005). Estudo do óleo essencial de algumas espécies do gênero Baccharis (Asteraceae) do sul do Brasil. Revista Brasileira de Farmacognosia, 15, 215-220. https://doi.org/10.1590/S0102-695X2005000300010

Bakkali, F., Averbeck, S., Averbeck, D., \& Idaomar, M. (2008). Biological effects of essential oils. Food and Chemical Toxicology, 46, 446-475. https://doi.org/10.1016/j.fct.2007.09.106

Bandeira, P. N., Pessoa, O. D. L., Trevisan, M. T. S., \& Lemos, T. L. G. (2002). Metabólitos secundários de Protium heptaphyllum March. Química Nova, 25, 1078-1080. https://doi.org/10.1590/S0100-40422002000 700006

Brandão, M. G. L. (2007). Produção de chás e extratos de plantas medicinais (Dossiê técnico). Fundação Centro Tecnológico de Minas Gerais (CETEC). Retrieved from https://sbrt.ibict.br/dossie-tecnico/downloads DT/MTc1

Citó, A. M. G. L., Costa, F. B., Lopes, J. A. D., Oliveira, V. M. M., \& Chaves, M. H. (2006). Identificação de constituintes voláteis de folhas e frutos de Protium heptaphyllum Aubl (March). Revista Brasileira de Plantas Medicinais, 8, 4-7.

Corrêa, R. M., Bertolucci, S. K. V., Pinto, J. E. B. P., Reis, E. S., \& Alves, T. L. (2004). Rendimento de óleo essencial e caracterização organoléptica de folhas de Assa-peixe submetidas a diferentes métodos de secagem. Ciência e Agrotecnologia, 28, 339-344. https://doi.org/10.1590/S1413-70542004000200013

Edris, A. E. (2007). Pharmaceutical and therapeutic potentials of essential oils and their individual volatile constituents: A Review. Phytotherapy Research, 21, 308-323. https://doi.org/10.1002/ptr.2072

Figueiredo, R. O., Delachiave, M. E. A., \& Ming, L. C. (2006). Reguladores vegetais na produção de biomassa e teor de óleos essenciais em Cymbopogon citratus (DC.) Stapf, em diferentes épocas do ano. Revista Brasileira de Plantas Medicinais, 8, 31-35.

Flora do Brasil. (2018a). Burseraceae in Flora do Brasil 2020 em construção. Jardim Botânico do Rio de Janeiro. Retrieved May 10, 2018, from http://floradobrasil.jbrj.gov.br/reflora/floradobrasil/FB68

Flora do Brasil. (2018b). Protium spruceanum in Flora do Brasil 2020 em construção. Jardim Botânico do Rio de Janeiro. Retrieved May 10, 2018, from http://floradobrasil.jbrj.gov.br/reflora/floradobrasil/FB6599

Gobbo-Neto, L., \& Lopes, N. P. (2007). Plantas medicinais: Fatores de influência no conteúdo de metabólitos secundários. Química Nova, 30, 374-381. https://doi.org/10.1590/S0100-40422007000200026

Hsieh, L. C., Hsieh, S. L., Chen, C. T., Chung, J. G., Wang, J. J., \& Wu, C. C. (2015). Induction of $\alpha$-Phellandrene on Autophagy in Human Liver Tumor Cells. The American Journal of Chinese Medicine, 43, 121-136. https://doi.org/10.1142/S0192415X15500081

Hussain, A. I., \& Anwar, F. (2008). Chemical composition, antioxidant and antimicrobial activities of basil (Ocimum basilicum) essential oils depends on seasonal variations. Food Chemistry, 108, 86-95. https://doi.org/10.1016/j.foodchem.2007.12.010

IAL (Instituto Adolfo Lutz). (1985). Normas Analíticas, Métodos Químicos e Físicos para Análises de Alimentos. (3rd ed., p. 533). São Paulo:Instituto Adolfo Lutz.

Lang, G., Mayhudin, N. A., Mitova, M. I., Sun, L., Van Der Sar, S., Blunt, J. W., ... Munro, M. H. G. (2008). Evolving trends in the dereplication of natural products extracts: New methodology for rapid, small-scale investigation of natural products. Journal Natural Products, 71, 1595-1599. https://doi.org/10.1021/ np8002222

Lima, D. F., Brandão, M. S., Moura, J. B., Leitão, J. M. R. S., Carvalho, F. A. A., Miúra, L. M. C. V., ... Almeida, F. R. C. (2011). Antinociceptive activity of the monoterpene $\alpha$-phellandrene in rodents: Possible mechanisms of action. Journal of Pharmacy and Pharmacology, 64, 283-292. https://doi.org/10.1111/j.2042 $-7158.2011 .01401 . \mathrm{x}$

Lima, T. A. A. C., Rocha, K. R. A., Melo, M. F. F., Marques, M. O. M., Facanali, R., \& Lima, M. P. (2014). Aspectos morfológicos e químicos de Protium spruceanum: Uma contribuição ao conhecimento das espécies aromáticas do bosque da ciência do INPA. Scientia Amazonia, 3, 6-10. 
Lin, J. J., Hsu, S. C., Lu, K. W., Ma, Y. S, Wu, C. C., Lu, H. F., .. Chung, J. G. (2016). Alpha-Phellandrene-Induced apoptosis in mice leucemia WEHI-3 cells in vitro. Environmental Toxicology, 31, 1640-1651. https://doi.org/10.1002/tox.22168

Loureiro, A. A., Silva, M. F., \& Alencar, J. C. (1979). Essências madeireiras da Amazônia. Manaus: INPA/Suframa.

Machado, B. F. M. T., \& Fernandes Junior, A. (2011). Óleos essenciais: Aspectos gerais e usos em terapias naturais. Cadernos acadêmicos, 3, 105-127.

Machado, L. B., Zoghbi, M. G. B., \& Andrade, E. H. A. (2003). Seasonal variation in the composition of the essential oils from the leaves, thin branches and resin of Protium spruceanum (Benth.) Engl. Flavour and Fragrance Journal, 18, 338-341. https://doi.org/10.1002/ffj.1238

Marco, C. A., Innecco, R., Mattos, S. H., Borges, N. S. S., \& Medeiros Filho, S. (2006). Influência de espaçamento, altura e época de corte no rendimento da biomassa e óleo essencial na cultura de capim citronela (Cymbopogon winterianus Jowitt.). Revista Ciência Agronômica, 37, 32-36.

Marques, D. D., Sartori, R. A., Lemos, T. L. G., Machado, L. L., Souza, J. S. N., \& Monte, F. J. Q. (2010). Chemical composition of the essential oils from two subspecies of Protium heptaphyllum. Acta Amazonica, 40, 227-230. https://doi.org/10.1590/S0044-59672010000100029

Martins, M. M. (2012). Constituintes voláteis, fenóis totais, capacidade antioxidante e biológica de folhas, flores e raizes da Vernonia brasiliana Less. (Master's thesis, Instituto de Química, Universidade Federal de Uberlândia, Uberlândia, Brazil). Retrieved from https://repositorio.ufu.br/handle/123456789/17366

Melo, M. F. F., Macedo, S. T., \& Daly, D. C. (2007). Morfologia de frutos, sementes e plântulas de nove espécies de Protium Burm. f. (Burseraceae) da Amazônia Central, Brasil. Acta botânica brasílica, 21, 503-520. https://doi.org/10.1590/S0102-33062007000300001

Moraes, M. M., Botelho, P. S., Neve, I. A., Neves, R. C. S., Ribeiro, N. C., Born, F. S., \& Camara, C. A. G. (2009). Composição química do óleo essencial das folhas de duas especies do gênero Protium (Burceraceae). Proceedings of the 9 Jornada de Ensino, Pesquisa e Extensão do Centro de Ensino de Graduação. Recife, Brazil: Universidade Federal Rural de Pernambuco.

Moretto, E., \& Fett, R. (1998). Tecnologia de óleos e gorduras vegetais na indústria de alimentos. São Paulo: Varella Editora e Livraria LTDA.

Oliveira, G. G. (2014). Identificação dos constituintes químicos e atividade biológica do óleo essencial de Trattinnickia burserifolia Mart. (Burseraceae) da Serra do Tepequém, Amajari-Roraima. (Master's thesis, Universidade Federal de Roraima, Boa Vista, Brazil). Retrieved from http://bdtd.ibict.br/vufind/ Record/UFRR_b8370a5db37c45fe5c684f52b85 8bccc

Pinho, R. S., Oliveira, A. F. M., \& Silva, S. I. (2009). Potential oilseed crops from the semiarid region of northeastern Brazil. Bioresource Technology, 100, 6114-6117. https://doi.org/10.1016/j.biortech.2009. 06.010

Pontes, W. J. T., Oliveira, J. C. G., Câmara, C. A. G., Lopes, A. C. H. R., Gondim Júnior, M. G. C., Oliveira, J. V., ... Schwartz, M. O. E. (2007a). Chemical composition and acaricidal activity of the leaf and fruit essential oils of Protium heptaphyllum (Aubl.) Marchand (Burseraceae). Acta Amazonica, 37, 103-110. https://doi.org/10.1590/S0044-59672007000100012

Pontes, W. J. T., Oliveira, J. C. S, Câmara, C. A. G., Lopes, A. C. H. R., Gondim Júnior, M. G. C., Oliveira, J. V., ... Schwartz, M. O. E. (2007b). Composition and acaricidal activity of the resin's essential oil of Protium bahianum Daly against two spotted spider mite (Tetranychus urticae). Journal of Essential Oil Research, 19, 379-383. https://doi.org/10.1080/10412905.2007.9699310

Pontes, W. J. T., Silva, J. M. O., Camara, C. A. G., Gondim Júnior, M. G. C., Oliveira, J. V., \& Schwartz, M. O. E. (2010). Chemical composition and acaricidal activity of the essential oils from fruits and leaves of Protium bahianum Daly. Journal of Essential Oil Research, 22, 279-282. https://doi.org/10.1080/10412905. 2010.9700324

Probst, I. S. (2012). Atividade antibacteriana de óleos essenciais e avaliação de potencial sinérgico (Master's thesis, Instituto de Biociências, Universidade Estadual Paulista, Botucatu, Brazil). Retrieved from https://repositorio.unesp.br/handle/11449/87926?show=full 
Ramos, M. F. S., Siani, A. C., Tappin, M. R. R., Guimarães, A. C., \& Ribeiro, J. E. L. S. (2000). Essential oils from oleoresins of Protium spp. of the Amazon region. Flavour and Fragrance Journal, 150, 383-387. https://doi.org/10.1002/1099-1026(200011/12)15:6<383::AID-FFJ927>3.0.CO;2-X

Rodrigues, I. V., Souza, J. N. P., Silva, A. C. G., Chibli, L. A., Cabral, V. A. R., Vieira Filho, S. A., ... Souza, G. H. B. (2013). Antiedematogenic and antinociceptive effects of leaves extracts from Protium spruceanum Benth. (Engler). Pharmacognosy Journal, 5, 6-12. https://doi.org/10.1016/j.phcgj.2012.08.001

Santos, G. A., Arruda, P. N. O., Brasil, M. C. O., \& Lacerda, G. A. (2017). Teor do óleo foliar de Assa-Peixe (Vernonanthura brasiliana (L.) H.Rob.) nativo da região norte de Minas Gerais. Revista Bionorte, 6, 12-23.

Silva, E. A. S. (2006). Estudo dos óleos essenciais extraídos de resinas de espécies Protium spp. (Master's thesis, Instituto de Química de São Carlos, Universidade de São Paulo, São Carlos, Brazil). Retrieved from http://www.teses.usp.br/teses/disponiveis/75/75132/tde-18012007-092324/pt-br.php

Silveira, J. C., Busato, N. V., Costa, A. O. S., \& Costa Junior, E. F. (2012). Levantamento e análise de métodos de extração de óleos essenciais. Enciclopédia Biosfera, 8, 2043-2052.

Silverstein, R. M. \& Webster, F. X. (2007). Spectrometric identification of organic compounds (7th ed., p. 512). Rio de Janeiro: LTC.

Siqueira, H. D. S., Neto, B. S., Sousa, D. P., Gomes, B. S., Silva, F. V., Cunha, F. V. M., ... Oliveira, F. A. (2016). $\alpha$-Phellandrene, a cyclic monoterpene, attenuates inflammatory response through neutrophil migration inhibition and mast cell degranulation. Life Sciences, 160, 27-33. https://doi.org/10.1016/j.lfs.2016.07.008

Tulp, M., \& Bohlin, L. (2004). Unconventional natural sources for future drug discovery. Drug Discovery Today, 9, 450-458. https://doi.org/10.1016/S1359-6446(04)03066-1

Zhangh, J. H., Sun, H. L., Chen, S. Y., Zeng, L., \& Wang, T. T. (2017). Anti-fungal activity, mechanism studies on $\alpha$-Phellandrene and Nonanal against Penicillium cyclopium. Botanical Studies, 58, 1-9. https://doi.org/ 10.1186/s40529-017-0168-8

Zoghbi, M. G. B., Andrade, E. H. A., \& Maia, J. G. S. (2002). Composition of the Essential Oils from Leaves, Wood, Fruits and Resin of Protiurn spruceanum (Benth.) Engl. Journal of Essential Oil Research, 14, 169-171. https://doi.org/10.1080/10412905.2002.9699813

\section{Copyrights}

Copyright for this article is retained by the author(s), with first publication rights granted to the journal.

This is an open-access article distributed under the terms and conditions of the Creative Commons Attribution license (http://creativecommons.org/licenses/by/4.0/). 